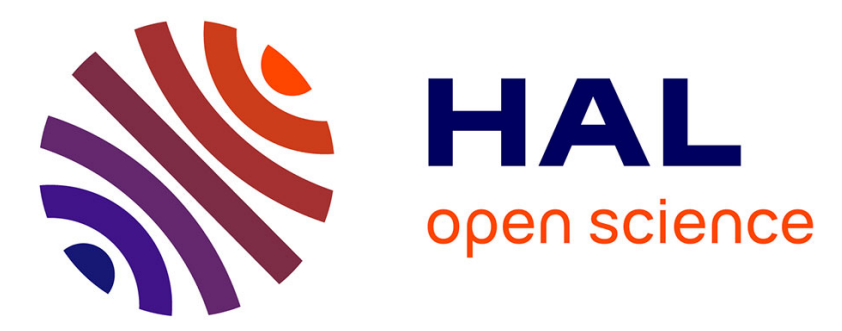

\title{
Recent Excavation and Recording at the New Neolithic Rock Art Site of Vallée Aux Noirs, Buthiers (Seine-et-Marne, France)
}

Serge Cassen, Valentin Grimaud, Laurent Lescop, Christophe Petit, Guillaume Robin

\section{To cite this version:}

Serge Cassen, Valentin Grimaud, Laurent Lescop, Christophe Petit, Guillaume Robin. Recent Excavation and Recording at the New Neolithic Rock Art Site of Vallée Aux Noirs, Buthiers (Seineet-Marne, France). Oxford Journal of Archaeology, 2018, 37 (2), pp.119-135. 10.1111/ojoa.12133 . hal-01869312

\section{HAL Id: hal-01869312 \\ https://hal.science/hal-01869312}

Submitted on 6 Sep 2018

HAL is a multi-disciplinary open access archive for the deposit and dissemination of scientific research documents, whether they are published or not. The documents may come from teaching and research institutions in France or abroad, or from public or private research centers.
L'archive ouverte pluridisciplinaire HAL, est destinée au dépôt et à la diffusion de documents scientifiques de niveau recherche, publiés ou non, émanant des établissements d'enseignement et de recherche français ou étrangers, des laboratoires publics ou privés. 


\title{
RECENT EXCAVATION AND RECORDING AT THE NEW NEOLITHIC ROCK ART SITE OF VALLÉE AUX NOIRS, BUTHIERS (SEINE-ET-MARNE, FRANCE)
}

\begin{abstract}
Summary. Following the exceptional discovery of Neolithic engravings on a boulder at Vallée aux Noirs in the Fontainebleau forest, south of Paris, an excavation trench was opened in order to access the buried part of the decorated rock panel and explore the stratigraphic context of the artwork. A palaeosol was found two metres below the modern ground level, underneath multiple layers of sterile sandy soil forming a very compact sequence from which only one archaeological artefact was recovered - an Iron Age fibula (c.200-300 BC). Dating of the palaeosol was attempted through two different methods: AMS dates from charcoal suggest a significant span from the Early Bronze Age to the Iron Age, while two more consistent OSL dates point to formation of the palaeosol during the Late Neolithic (3500-3000 cal BC). The entire engraved rock surface $\left(16 \mathrm{~m}^{2}\right)$, including its buried part, was fully recorded. Four main semiotic groups were identified: a typical fifth-millennium crook-hafted axe with a ring, two boats with steering oars, and a central, very tall human figure dominating the composition from its 3.5-metre height.
\end{abstract}

\section{DISCOVERY OF THE SITE AND RESEARCH OBJECTIVES}

In 2013 a visit was organized to the grotte de La Hache ('Cave of the Axe') in Buthiers, Seine-et-Marne, in order to undertake a new recording of the site's long-known engravings of Neolithic axes (Baudet 1950). The cave is located on the upper part of the southern margin of a dry valley leading down to the river Essonne. The dramatic landscape here includes large sandstone boulders resulting from the erosion of the valley slopes and whose 'megalithic' aspect may well remind archaeologists of Neolithic monuments around Carnac in Brittany. The engraved figures of the region provide another virtual link with south Brittany. Several rock art sites on the western edge of the Fontainebleau forest include engraved hafted axes of Breton affinity, which led us to study a number of them, including the caves of Bel Air 13 and Vallée aux Noirs 1 (or grotte de La Hache - Fig. 1). Several prehistorians in the early twentieth century emphasized the formal similarities between these few 'axe' signs (both hafted and unhafted) from the Essonne valley 


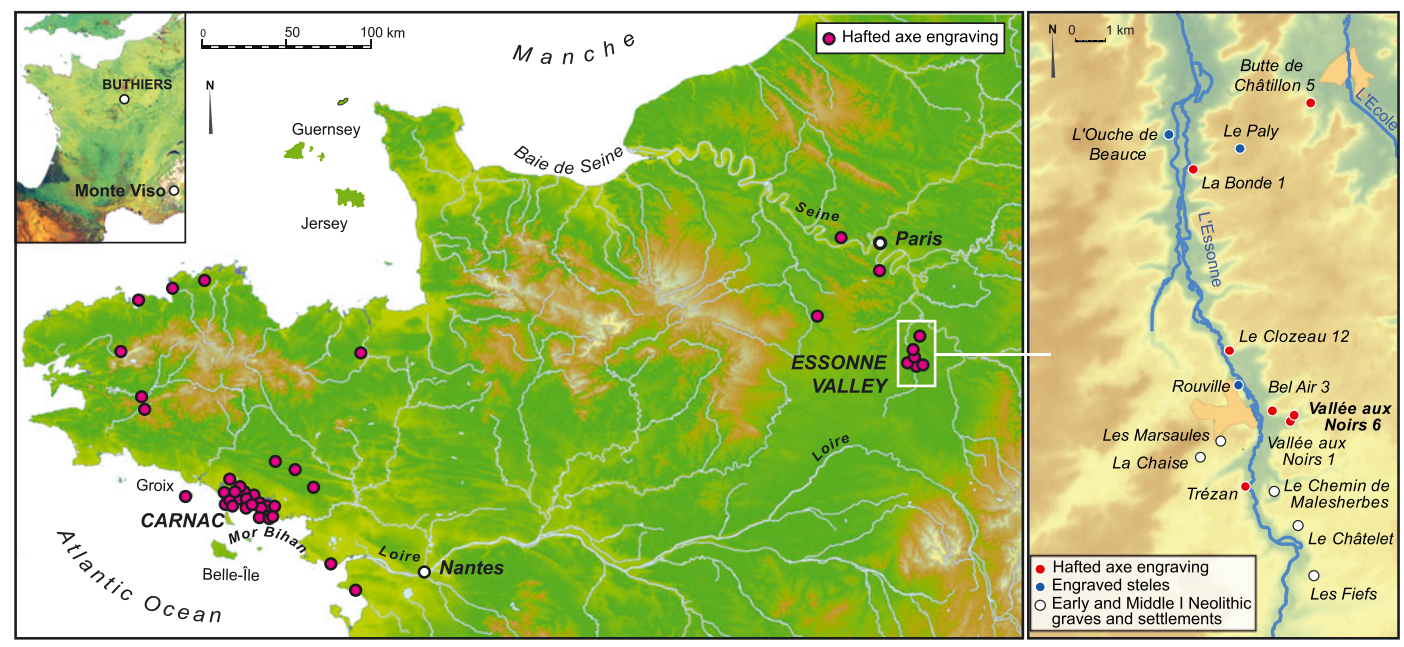

Figure 1

Left: distribution of engravings of hafted axes from the fifth and fourth millennia BC in north-western France. Right: the Essonne valley with locations of the main Neolithic sites and engravings (adapted from Cassen et al. 2014a). [Colour figure can be viewed at wileyonlinelibrary.com]

and those known in Morbihan, particularly the axe motifs in the Gavrinis and Table des Marchands passage tombs (Courty 1913; Baudet 1950). We took the opportunity of our visit to the grotte de la Hache to survey the surrounding area and in fact discovered a new series of engravings on a large rock standing naturally in the sand further down in the valley, which was subsequently called Vallée aux Noirs 6 (Cassen et al. 2014a; 2014b).

The new recording campaigns of the Essonne motifs were carried out as part of the larger on-going JADE 2 project (Pétrequin et al. 2012; 2017), the aim of which is to further investigations into polished jade axes of exceptional dimensions and finish, as well as fine stone rings, and to identify the sources in the Alps. In the north of France, jade axes (and rings) were socially valued objects from the early fifth millennium BC onwards. They were diffused all over western Europe, with a remarkable concentration in the Carnac region where they were deposited within three outstanding burial mounds (Mané er Hroëck, Tumiac and Mont Saint-Michel) as well as at significant natural topographic features (outcrops, wetlands - Cassen et al. 2010). Key questions addressed by the project are: (1) whether the engraved axe motifs from Brittany (especially in Morbihan, where most of the French examples are found), Switzerland and Italy could correspond to the various morphological types of the actual Neolithic jade axes identified in the project (Pétrequin et al. 2012); and (2) whether the iconographic types from the Carnac region may have influenced the style of axe motifs in the regions located along the diffusion routes from Monte Viso, the principal source of the Alpine jades (jadeitites, fine-grained eclogites, omphacitites).

These questions are discussed in detail in special chapters of the third and fourth monographs of the JADE project (Pétrequin et al. 2017). Our objective here is rather to present and discuss the results of field investigations that were carried out in 2014 at the new rock art site of Vallée aux Noirs 6 in Buthiers. The engravings are located at the bottom of the northern face of the large boulder. At the time of the discovery, it was clear that some motifs, such as the lower part of the hafted axe, extended down to the buried part of the rock face (Fig. 2). The aim was to 


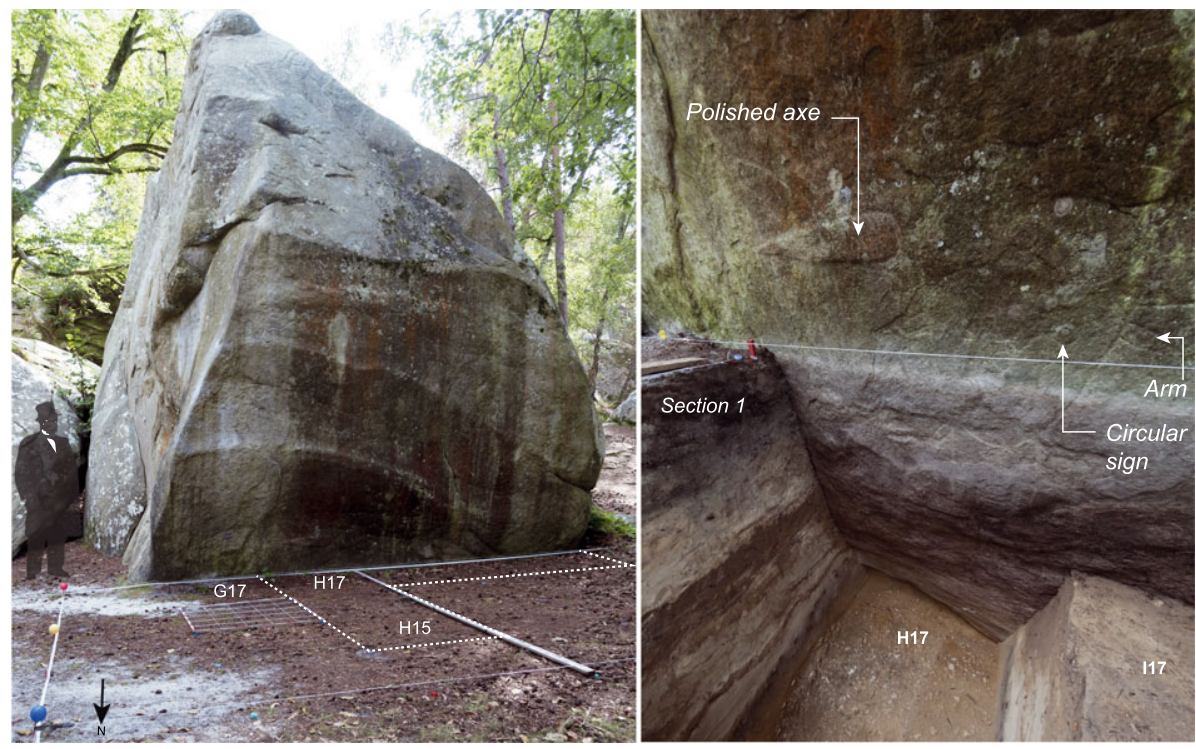

Figure 2

Left: the northern face of the Vallée aux Noirs 6 boulder, with layout of the excavation trench. Right: view of the trench at the end of the excavation, showing section 1 and the gravel substratum at the base of the boulder (photos: S. Cassen).

[Colour figure can be viewed at wileyonlinelibrary.com]

open a small excavation trench at the base of the decorated rock face in order, first, to access the buried part of the art and to produce a complete recording of the engravings, and, second, to examine the stratigraphic sequence of accumulated sediment associated with this context. Dating rock art is a challenge and therefore two different yet complementary methods were used to produce direct and indirect dates for the creation of the decorated panel: AMS radiocarbon dating (C14) and optically stimulated luminescence (OSL). Lastly, this article will discuss the sequence of execution of the most complex motifs: the hafted axe and the standing anthropomorphic figure.

\section{LAYOUT OF THE TRENCH AND DESCRIPTION OF THE STRATIGRAPHY}

Priority was given to uncovering the lower part of the hafted axe and the excavation trench was laid out accordingly. The L-shaped trench was aimed at revealing the base of the rock face and creating a perpendicular section with intermediate levels within this presumably unstable sandy context. The excavation grid was orientated to magnetic north (Fig. 3) and to make it easy for the researcher to face the engravings, i.e. with the $\mathrm{x}$-axis parallel to the boulder face and the $\mathrm{y}$-axis running north to south.

A preliminary sedimentary investigation was made through a series of 80-100 cm deep core samples taken at five-metre intervals from the eastern angle of the rock down to the path to the north (Fig. 3). They revealed that no organic layer was present here within the essentially sandy soil. The excavation trench was recorded with photogrammetry, with a 3D model for each of the 13 phases of excavation (Fig. 4 - see Lescop 2016 for further technical information). The xyz coordinates of the excavated artefacts were also recorded during fieldwork with individual ad hoc 


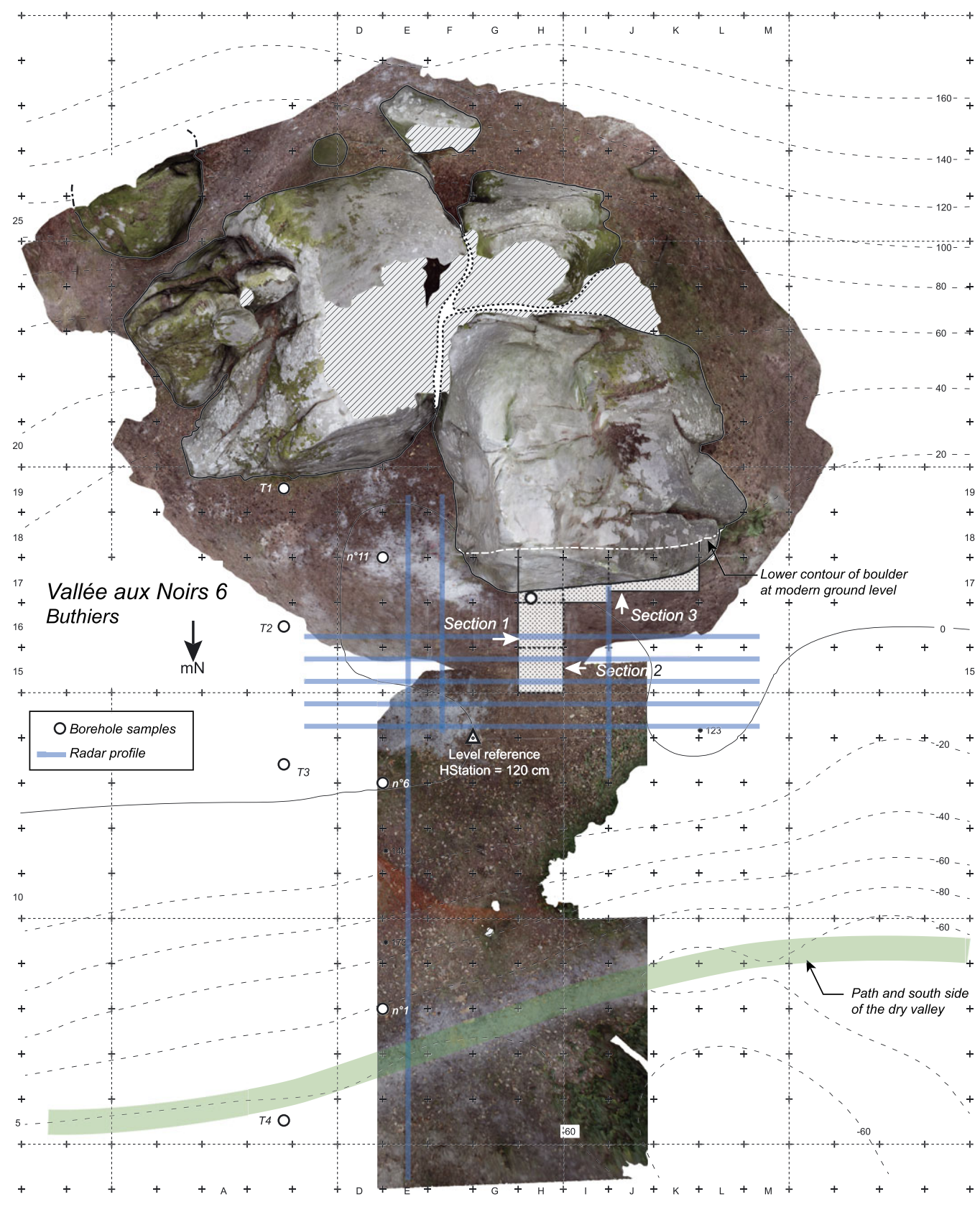

Figure 3

Plan of the site grid based on the photogrammetric model, with location of the excavation trench and stratigraphic sections at the base of the engraved boulder, and the core samples (CAD: S. Cassen and V. Grimaud). [Colour figure can be viewed at wileyonlinelibrary.com] 

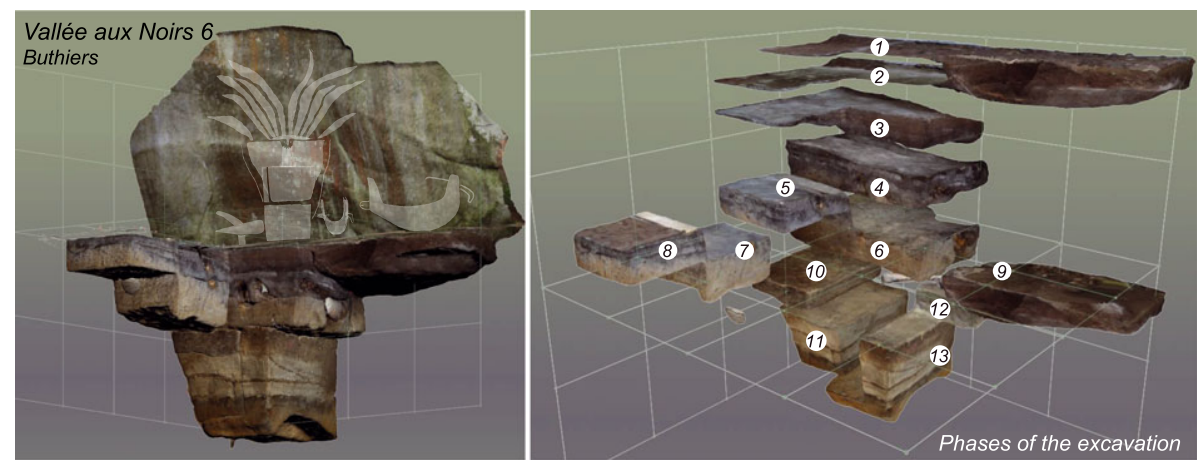

Figure 4

Left: view of the 3D model showing the engraved face of the boulder and the exterior surfaces of the excavation trench. Right: split view of the different phases of excavation from phase 1 (ground surface) to 13 (western bank and bottom layer) (3D model: L. Lescop). [Colour figure can be viewed at wileyonlinelibrary.com]

sheets, together with the colour and texture of their associated stratigraphic unit. This process worked well but could not be used to the extent we had hoped, since the trench produced no archaeological features that could have been virtually reconstructed at the post-excavation stage. However, considering that only one square metre of the bottom of the trench was uncovered, corresponding to a very small portion of the floor level plausibly contemporary with the execution of the engravings, it is quite possible that associated features such as scaffolding pits or hearths remain to be found in the remaining $c .30 \mathrm{~m}^{2}$ of the natural platform next to the engraved rock face that are still to be excavated.

The engraved boulder, a dihedral pyramidal block, stands six metres above the present-day ground level (Fig. 2) and is one of the tallest in this area of the Vallée aux Noirs. The valley was planted with pine trees in the nineteenth century. Geologically, it results from the erosion of the Fontainebleau Sandstone layer (Stampian marine sandstone, G2b, Oligocene) typical of the Fontainebleau Forest plateau whose top layer is made of lacustrine sandstone (Upper Stampian siliceous or soft sandstone). The bottom of the Vallée aux Noirs is probably sealed with sandygravel colluvium as well as peat alluvium near the Essonne valley (ongoing survey: information from C. Petit; DocOb Natura 2009).

The stratigraphic section on the east side of the trench (section 1, Fig. 5) was examined, with particular attention to sedimentology and pedology. Thirteen random samples were taken for granulometric analyses (dry sieving with vibrating column), and two block samples for micromorphology (Prl1 and Prl2) to assess facies variability. The samples correspond to the lithological variations identified in the site. However, attempts to find pollen in the most clayey levels were unsuccessful. The excavation trench, dug down to a compact layer of sandstone congelifracts, enabled us to investigate a $2 \mathrm{~m}$-high stratigraphy at the base of the engraved boulder and to reveal several pedo-sedimentary units whose sequence will be summarized briefly here.

Apart from the first sample (P1, Fig. 5), composed of mixed gravel sands, the sedimentary series is principally made up of medium sands ( 0.125 to $0.315 \mathrm{~mm})$. Clayey-loamy levels are clearly visible (P5, P10 and P11). A comparison of the different samples (granulometry in cumulated percentage) shows that sample P1 is poorly sorted (all fractions are represented), while the other samples are well sorted with various degrees of clay and loam up to 40\% (P5: 52\%; P1: 28\%; P11: 38\%). These clayey-sandy levels correspond to thin colluvium deposits with pedogenesis 
Vallée aux Noirs 6

Buthiers

SECTION 1

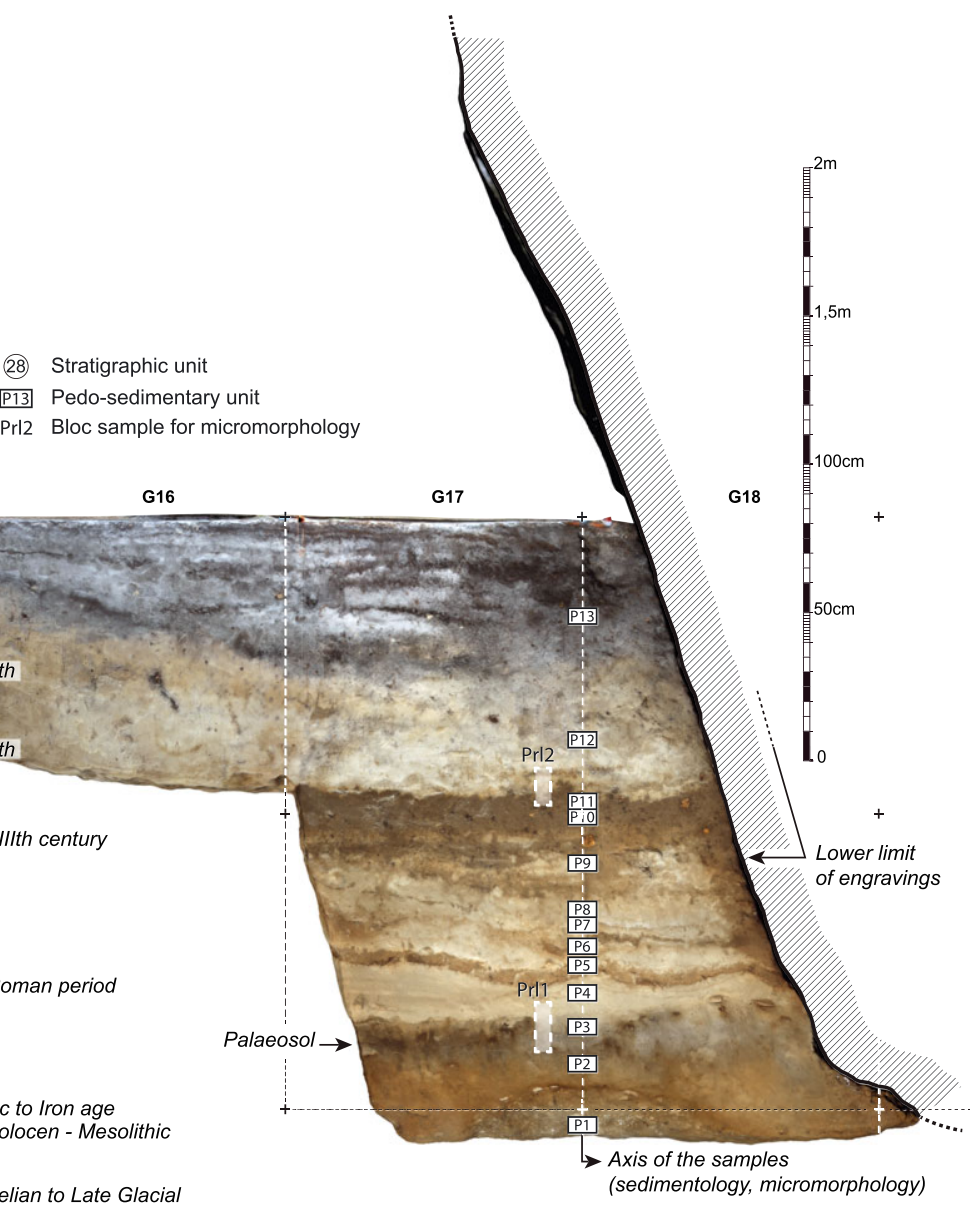

Figure 5

Section 1. Mosaic orthophoto and stratigraphic drawing showing the pedo-sedimentary units and the location of the block samples for micromorphological analyses (CAD: S. Cassen, V. Grimaud and L. Lescop). [Colour figure can be viewed at wileyonlinelibrary.com]

development at P5 and P11. These granulometric analyses show that the siliceous sands and gravels result from the erosion of the Fontainebleau sandstones, while the loamy clays originated further up in the cultivated higher ground where plateau loams occur.

This first geoarchaeological analysis enabled us to reconstruct the main phases of geomorphological evolution of the valley slope and confirm that the floor level associated with the creation of the engravings is located $1.6 \mathrm{~m}$ below the present-day surface (Figs. 5 and 6 ). These results will be augmented by further analyses, including sample micromorphology and further coring in the Vallée aux Noirs. In the meantime, our initial sound results show the following stratigraphic sequence for the base of the engraved boulder and the wider context:

- P1: Weichselian to Late Glacial: deposition of cryoclastic limestone debris under a periglacial climate with occurrence of a permafrost with seasonal thaw. 

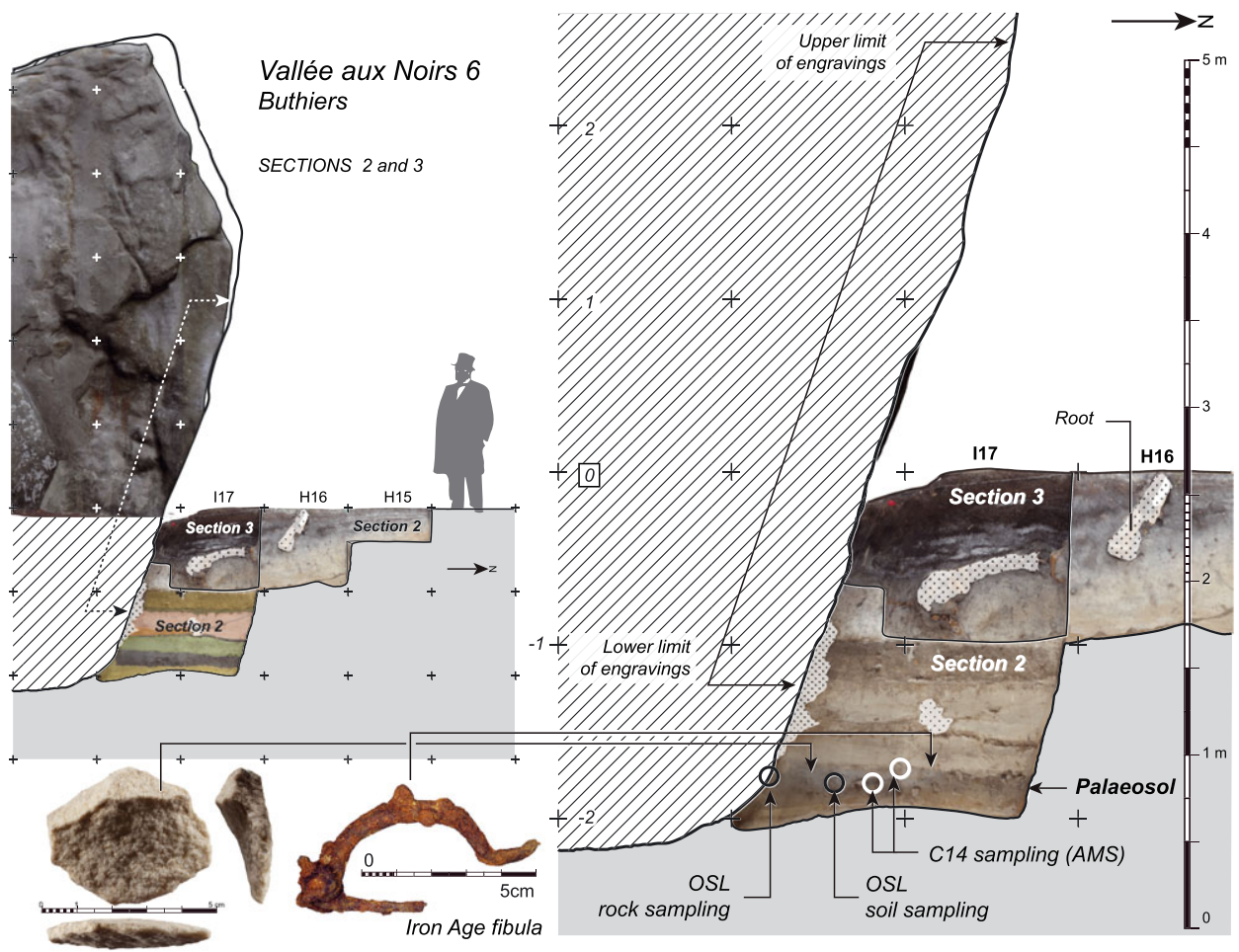

Figure 6

Sections 2 and 3, with location of the OSL and C14 samples, and of the sandstone flakes and iron fibula in the palaeosol (photos: N. Mather, Carnac museum; CAD: S. Cassen, V. Grimaud). [Colour figure can be viewed at wileyonlinelibrary. com]

- P2-P3: Initial Holocene: deposition of colluvial and/or Aeolian sandstone sands; the Fontainebleau Massif is settled by Mesolithic groups (Bénard and Guéret 2014).

- P3 upper: Early Holocene-Neolithic-Iron Age: geomorphological stability under forest cover where a soil little affected by human activities develops.

- P4-P11: formation of two coalescent alluvial cones at the foot of the boulder; recurring fast hydrodynamic events probably contemporary with Gallo-Roman(?) cultivation of new lands causing run-off on open surfaces.

- P11: development of a forested soil at the foot of the boulder while agro-pastoral, Gallo-Roman activities are identified regionally.

- P12 base: local erosion, trampling associated with animal(?) presence at the foot of the boulder during modern times.

- P12: quartz colluvium resulting essentially from gravity, rare(?) vegetal cover; contemporary with modern agro-pastoral farming.

- P13: sandy-organic local gravity-induced colluvium, scotch pine cover with local development of touristic activities (climbing...) in a highly cultivated region during the contemporary era.

To conclude, the fine and barely cohesive sands of Fontainebleau live up to their (poor) reputation of providing very little reliable stratigraphy for late prehistoric sites (Tarrête 1977; Hinout 
1993). At Vallée aux Noirs 6, a palaeosol was sealed beneath several historic accumulations reflecting major transformations caused by increasingly intensive agricultural activity on the surrounding fertile plateaus, probably since the Gallo-Roman period. This palaeosol provides an indication of the topographic level from which the rock surface of the boulder was dressed and engraved.

\section{THE CHRONOLOGICAL FRAMEWORK: MATERIAL CULTURE AND DATES (C14, OSL)}

Figure 5 shows the correspondence between the stratigraphic units (layers 1-28) and the pedo-sedimentary units as identified respectively by the archaeologists and sedimentologist writing this article. In both sequences, unit 3 corresponds to a brown palaeosol in which two different types of artefact were discovered. The first are large sandstone flakes, including one obviously resulting from deliberate percussions on the rock surface as part of its dressing process (Fig. 6). The second artefact is a fibula, whose archaeological date is more straightforward. It was found near the top of the palaeosol in grid square H17 (see section 2, Fig. 6) and can be dated typologically to the second or third centuries BC (Baray 2016). This dress accessory may be associated with a disturbed burial in the immediate vicinity of the trench. It also shows that unit 3 (the palaeosol) does not correspond to a single, consistent historic phase but rather to an extended period of time. The radiocarbon and OSL dating will corroborate this observation.

Indeed, it seemed important to us to collate results from two different dating methods. The stratigraphic context at Vallée aux Noirs and Fontainebleau is generally reputed for its taphonomic aggressiveness, affecting not only the preservation of artefacts but also their stratigraphic contexts, which are often disturbed by the fluidity of the sand.

\section{Radiocarbon dating}

Charcoal recovered from the top and middle of unit 3 was sent to the Accelerator Mass Spectrometry Laboratory of Tucson (University of Arizona, Department of Physics) (Table 1).

The first result is consistent with the fibula found in the upper part of the palaeosol. The date of the second charcoal sample, retrieved $10 \mathrm{~cm}$ down in the layer, was more unexpected (Early Bronze Age).

\section{OSL dating}

A laboratory specializing in OSL sampling and dating (SAS Re.S.Artes, Bordeaux) was called into the project in order to determine the last time the rock surface was exposed to daylight at the supposed ground level frequented by the Neolithic engravers. To do so, two sampling strategies were used: a sample (S214035) was taken from the aeolian sediments of layer 3 (from

TABLE 1

Results of the AMS dates from two charcoal samples recovered from the palaeosol (unit 3)

\begin{tabular}{llllll}
\hline Vallée aux Noirs 6 & Reference & Sample type & Lab code & Date BP & Date BC (2 $\sigma)$ \\
(Buthiers) & VN6 H17-PS1: upper palaeosol & charcoal & AA105061 & $2518 \pm 54$ & $-801,-431$ \\
& VN6 G17-PS2: palaeosol & charcoal & AA105062 & $3644 \pm 28$ & $-2134,-1927$ \\
\hline
\end{tabular}


which the AMS-dated charcoal samples also come), and another one (S214037) from the rock face itself whose surface was covered by the sediment of layer 3 .

The OSL dates are as follows:

Soil sample: T $(\mathrm{S} 214035)=4970 \pm 590 \mathrm{BP}[3550-2370] \mathrm{BC}$

Rock sample: T $(\mathrm{S} 214037)=5580 \pm 610$ BP [4180-2960] BC

The two dates present an overlap of 590 years. They can therefore be regarded as contemporaneous in the mathematical sense. However, a mean date will not be proposed here in the absence of evidence that the two samples belong to strictly the same archaeological context.

What should be concluded about the date of the probable level of execution of the engravings?

Taking into account the 500-year overlap between both dates, a common date range of 3500-3000 cal BC can be put forward for the creation of the palaeosol and the concealment of

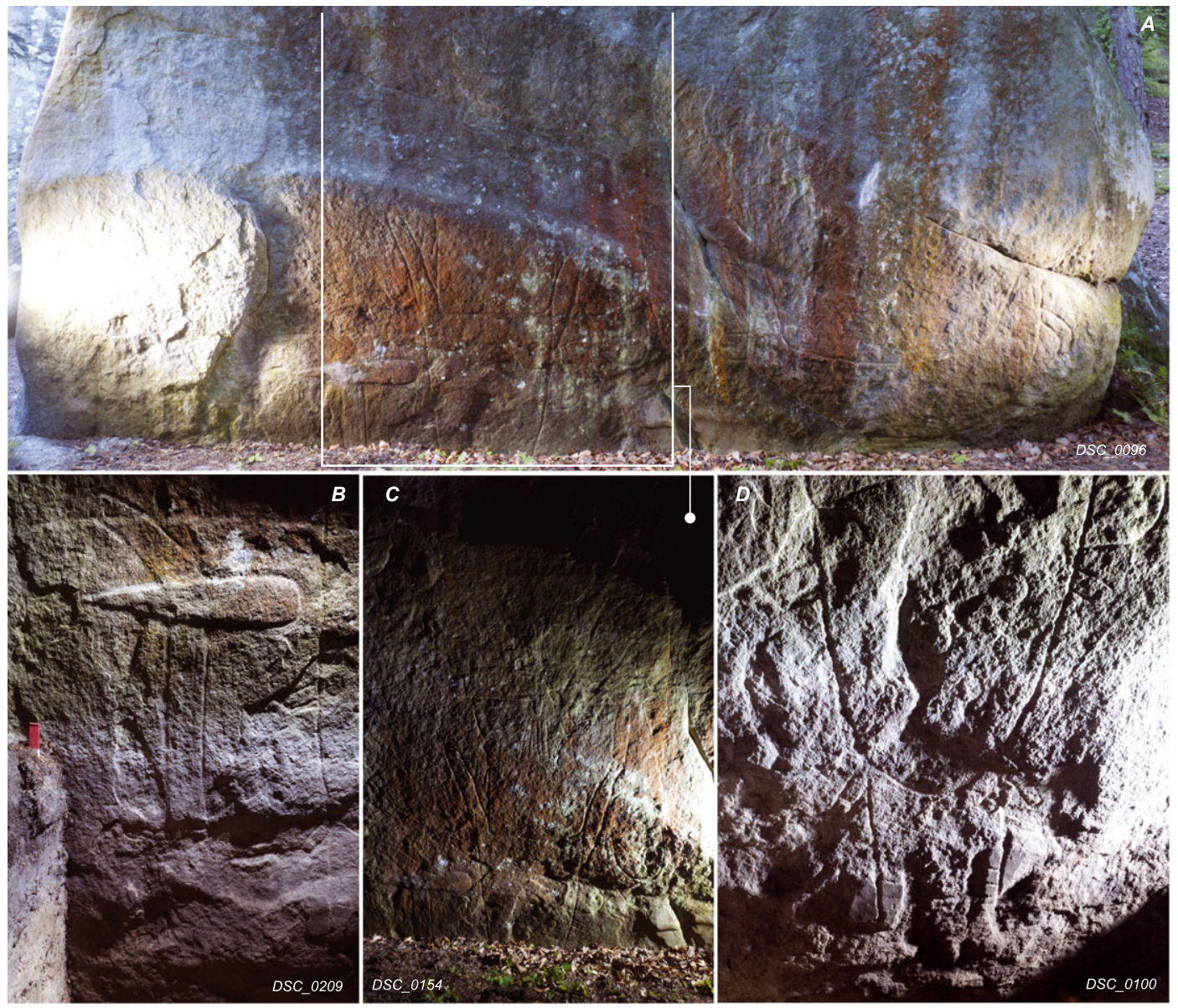

Figure 7

Photographs of the engraved panel before (A. general; C. anthropomorphic figure) and after (B. stone axe motif; D. lower part of the anthropomorphic figure) the excavation (photos: S. Cassen). [Colour figure can be viewed at wileyonlinelibrary. com] 
the rock face at the base of the boulder. In other words, the sediment phase dates to the Late Neolithic. Radiocarbon dates from organic material, on the other hand, do not corroborate this chronological determination: the time difference between the two samples (Early Bronze Age and Iron Age) within this single layer rules out further extrapolations. An extension of the excavation trench could provide additional datable materials to complement the currently limited results: stake holes from a probable scaffolding, for example, could be found within the gravel underneath the palaeosol and could determine a more exact date for the execution of the engravings. This natural gravel layer represents the minimal Neolithic ground-surface level, given that the depth of the layer beneath it is difficult to evaluate.

\section{GEOPHYSICAL SURVEY}

Two areas were surveyed in order to map out the geometry of surface features in the immediate vicinity of the engraved boulder, such as the top part of buried sandstone rocks or potential archaeological features. The first survey $(160 \times 60 \mathrm{~m})$ focused on the bottom of the valley c.30 m north of the engraved boulder, and the second around and in front of the engraved panel. Two methods were used: electrical conductivity and georadar. The results were consistent with those of the core samples and indicated layers of sandy colluvium up to at least $3.2 \mathrm{~m}$ deep (the maximum range of the geophysical equipment), within which a few sandstone blocks appeared as anomalies. Other anomalies in front of the engraved boulder were detected high up in the stratigraphy $(50 \mathrm{~cm}$ from modern ground level) and therefore could correspond to recent agropastoral structures. The palaeosol was recorded in the georadar profiles: horizontal in front of the

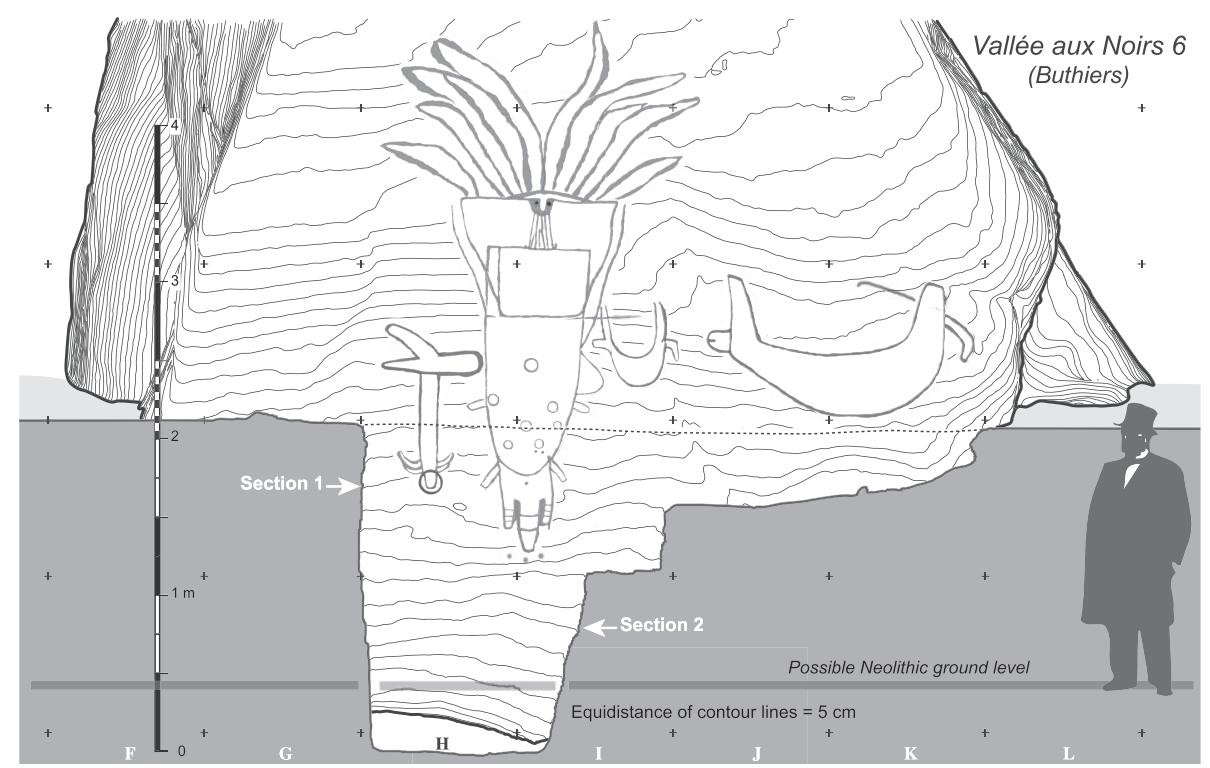

Figure 8

Orthogonal front view of the engraved panel, with a cross-section of the excavation trench (CAD: S. Cassen and V. Grimaud). 
boulder and then sloping down towards the valley bottom. However, no features were detected at this level.

\section{THE ENGRAVED COMPOSITION}

After three-dimensional recording of the rock panel using photogrammetry, the engravings were recorded using photographs and radial oblique lights. Both types of data (2D and 3D) were
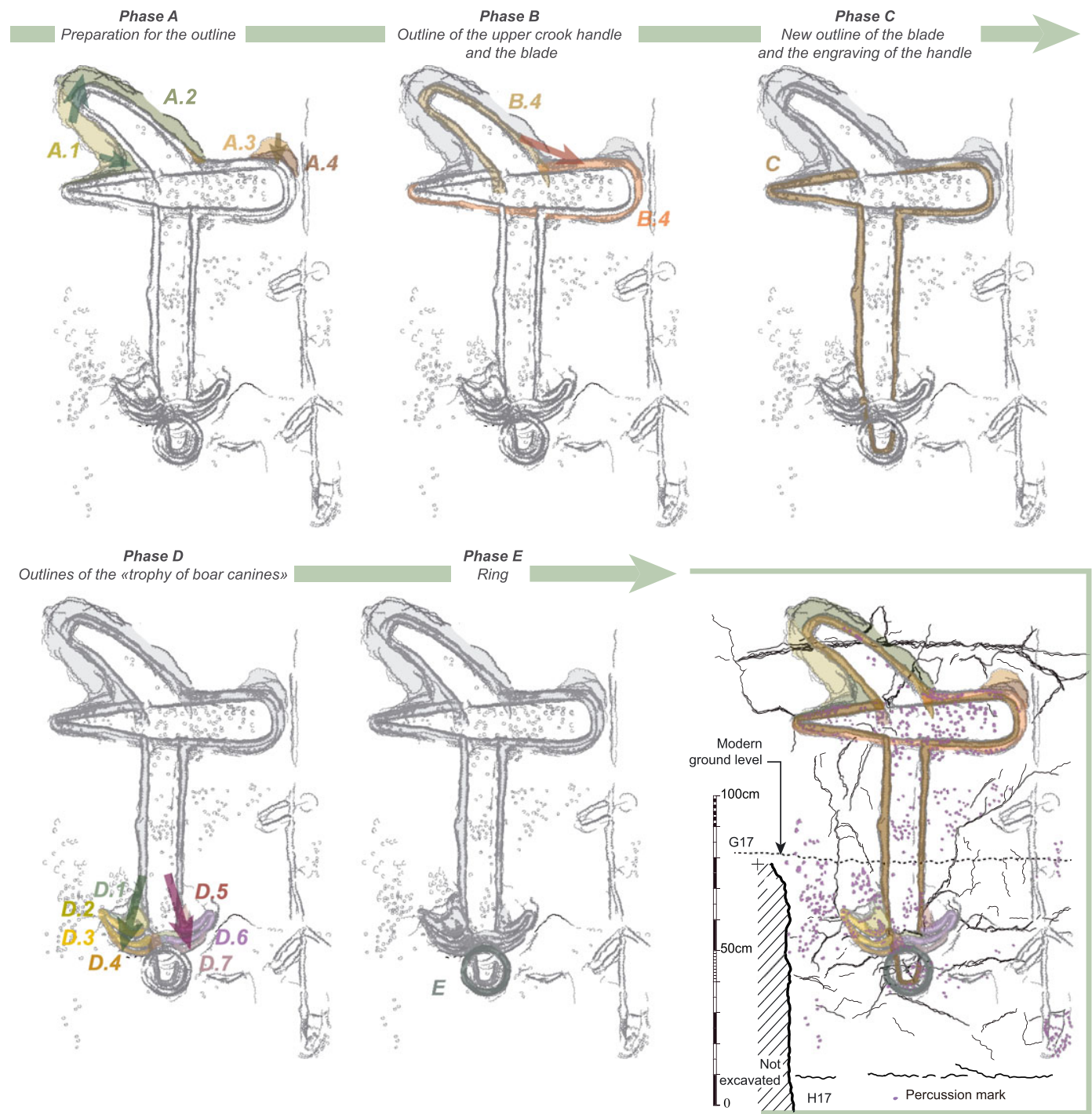

Figure 9

Sequence of the execution phases of the hafted axe motif (CAD: S. Cassen). [Colour figure can be viewed at wileyonlinelibrary.com] 
then merged together following a now well-established protocol (Grimaud and Cassen 2016). Four motifs had been identified (and interpreted) before the opening of the trench (Cassen et al. 2014a): an anthropomorphic figure which dominates the scene (Fig. 7), a hafted stone axe standing on the left side of the panel, and two boats without passengers on the right. The two boats are of different sizes, with the smaller one touching the anthropomorphic figure. The excavation enabled us to access the buried part of the engraved panel and therefore to reveal the missing (lower) parts of the axe and the anthropomorphic figure (Fig. 8). No hidden motifs were found below the boats.

Compared to the exposed rock surface, the buried surface does not seem to have been particularly better preserved from weathering or, conversely, more affected by long contact with the fluid soils or roots. Well-preserved tool marks were identified in various areas and revealed different processes: the preparation of the rock surface (some percussion has removed stone chips of up to $1 \mathrm{~cm}$ ), the reduction of natural projections and the linear engravings of the motifs. It was noted, however, that the engravings of the lower part of the axe were less sharp than for the exposed part of the motif, but it is not clear whether this is due to pedological agents or to the altered nature of the rock. Yet, missing small plaques show that the stone surface was subject to flaking during the last three centuries before it was sealed under sands.

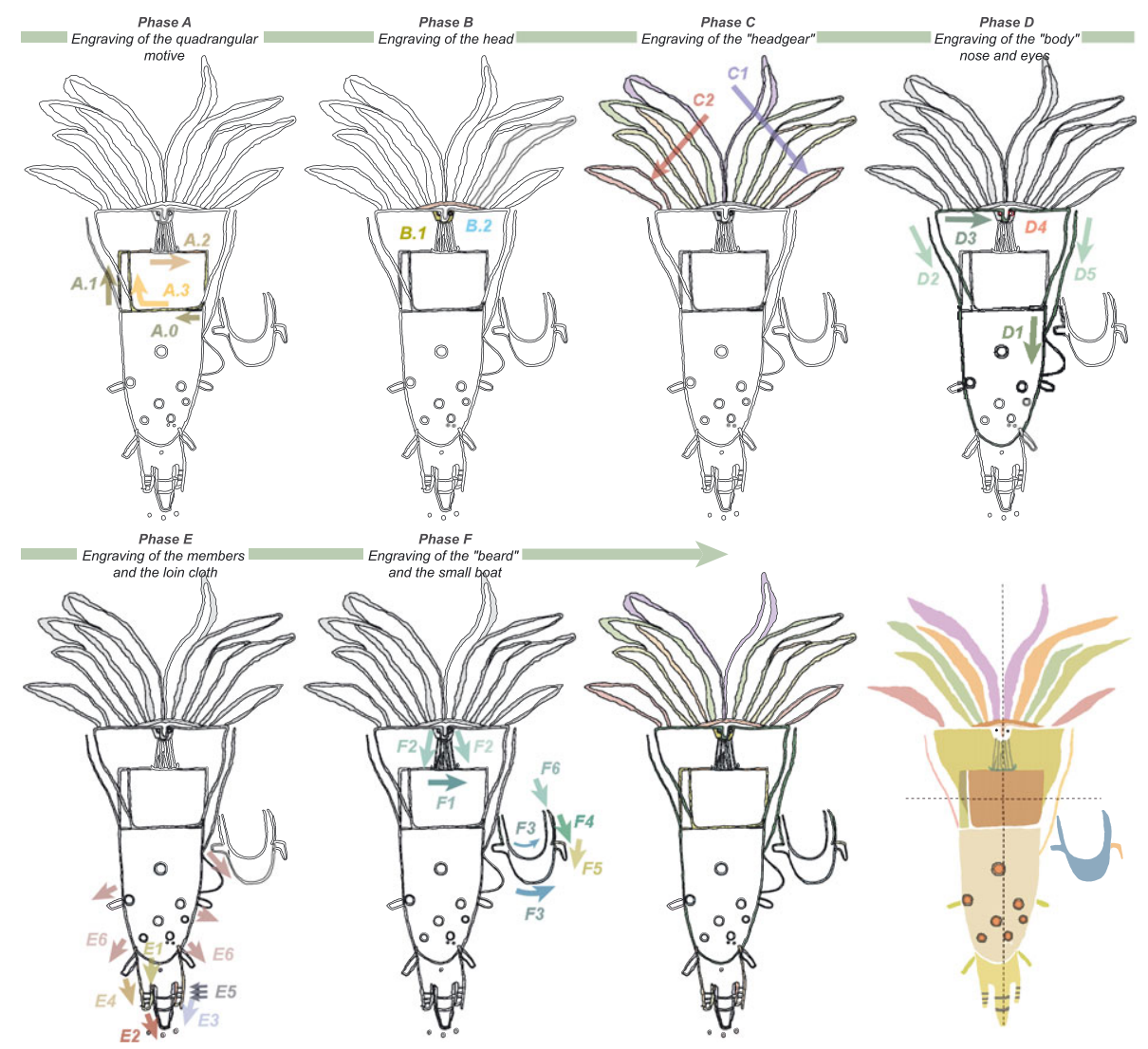

Figure 10

Sequence of the execution phases of the anthropomorphic and small boat motifs (CAD: S. Cassen). [Colour figure can be viewed at wileyonlinelibrary.com] 
The new engravings uncovered during the excavation are of particular interest. At the lower end of the haft of the axe (Figs. 8 and 9), on a surface particularly well prepared by at least two types of stone tools, a ring motif of $16 \mathrm{~cm}$ diameter was engraved during the latest phase of execution of the composition. The ring can be interpreted as the representation of a bracelet or, more specifically, a 'disc-ring' (anneau-disque) (Cassen et al. 2017). Above the ring are two symmetrically arranged pairs of 'horned' curvilinear signs, with the upper pair larger than the lower. They may correspond to a type of body ornament. Compared to the scale of the axe, they would be too small to be interpreted as animal horns (e.g. cattle). We suggest that they can be seen as the lower and upper canines (tusks) of a male wild boar, fixed as trophies to the haft of the weapon. Such a combination is known archaeologically from the famous 'tombe du chef' at Pauilhac (Gers, south-west France), which yielded a large jade axe head deposited with boar tusks laid out in a 'crescent-like' arrangement (Roussot-Larroque 2012).

The lower part of the anthropomorphic figure was also easily recognized and recorded on the excavated rock surface, with its contour delimited by a single engraved line. The overall figure is quite similar to another motif engraved on the Rouville standing stone, only $2 \mathrm{~km}$ north of Buthiers (Devilliers 2005; Bénard 2011). The atrophied form of a possible 'arm' was identified on the Rouville stone: similar small 'arms' and 'legs' were potentially represented on the sides of the body at Vallée aux Noirs. Interestingly, as at Rouville, an intriguing three-part motif is represented between the legs, which we suggest could be interpreted as the representation of a loincloth made from the hide of a wild cat (see Cassen et al. 2017 for further discussion). Finally, six circular motifs were recorded inside the lower body of the anthropomorphic figure, distributed into two groups of different diameters: the first group (four motifs of $9 \mathrm{~cm}$ ) above the second (three motifs of $7 \mathrm{~cm}$ ). One cannot be sure whether these motifs were intended as rings or plain discs, but the latter could have technically been achieved if needed in the form of a circular relief similar to that obtained for the axe head motif, which suggests that rings were intended.

\section{COMMENTS AND CONCLUSIONS}

The site of Vallée aux Noirs 6, on the western edge of the Fontainebleau forest, represents an exceptional discovery in terms of the nature and dimension of its unique engravings, the quality of their execution and their state of preservation. Following the discovery, a small-scale excavation was carried out in order to explore the buried part of the rock panel and its associated stratigraphy and potential archaeological material. A $6 \mathrm{~m}^{2}$ trench was opened, including one square metre (H17-18) reaching down to the geological substratum $2.15 \mathrm{~m}$ below the modern ground level. This has revealed a palaeosol with a very compact sequence and within which only one archaeological artefact was recovered, an Iron Age fibula (200-300 cal BC) probably associated with a burial nearby. The excavation has also yielded several sandstone flakes resulting from intentional percussions on the panel, as well as a thin rock plaque flaked off the rock surface and still bearing a subtle dressing, which all show the significant level of work that was undertaken to prepare the rock surface for the artwork. The palaeosol represents the general floor level from which the panel was executed. The rock face was dressed 50-80 cm upwards from this Neolithic ground-surface. The dressing was aimed at reducing the natural irregularities and angles of the rock surface in order to create a relatively smooth and flat surface not only for the execution of the motifs, but also to frame the entire composition. It may also have prevented engraving errors by removing the fragile outer layer of the sandstone surface affected by natural flaking. 
It was not possible to achieve congruent dates for the palaeosol from the two dating methods used. The two charcoal samples that were AMS-dated suggest a long period spanning the Early Bronze Age to the Iron Age, while the OSL dates, which were internally relatively consistent, show that the palaeosol was created during the Late Neolithic (3500-3000 cal BC). Also, it is surprising not to have found earlier 'archaeological' sediment material at the foot of the boulder, such as Upper Palaeolithic and Mesolithic layers, considering that they have been recorded in many parts of the region where environmental conditions have allowed good preservation of stratigraphies. Above the dark grey palaeosol, a succession of various thick layers (light yellow sands and light brown clay-sands) rests against the boulder, creating a sequence initiated during the Gallo-Roman period and covering up the engravings from the sixteenth/eighteenth centuries $\mathrm{AD}$ onwards, certainly as a result of large-scale agriculture on the fertile plateaus surrounding the site. After their creation during the Neolithic, the engravings have therefore been exposed to weathering until a few centuries ago, which explains the consistent state of preservation across the buried and exposed surfaces of the panel, in particular the lower exposed surface which is protected from rainfall by the inclination of the rock face.

Material culture typology can provide further dating evidence for the period during which the panel was engraved. For instance, the large axe head motif matches a particular type originating from south France, the Bégude type (Cassen et al. 2014c). Bégude is the earliest type within the European classification of Neolithic jade artefacts (Pétrequin et al. 2012) and represents socially valued axes which were already circulating as far as the Paris basin in the early fifth millennium BC. However, each engraved sign has its own temporality which may differ slightly from the actual reference object. As a consequence, their respective chronologies may not correspond exactly.

Vallée aux Noirs 6 represents the largest Neolithic engraved panel of the region. Engravings were found down to $1.2 \mathrm{~m}$ below the modern ground level and the anthropomorphic figure stands $2.6 \mathrm{~m}$ above it, giving a height of $3.8 \mathrm{~m}$ for the panel. The composition spreads horizontally across $4.1 \mathrm{~m}$ of the rock face, which makes a total surface of $16 \mathrm{~m}^{2}$ for the entire panel. Four semiotic groups have been identified: three objects (a crook-hafted axe and two boats with steering oars) arranged around a central, very tall anthropomorphic figure. On the left, the active, cutting edge of the axe head is directed towards the anthropomorphic body. On the right, the prows of both boats are directed towards the centre of the composition, and the largest motif lies upon a natural wave-like fold in the rock that wraps the body of the anthropomorphic figure and from which its head 'emerges'. The quadrangular motif within the 'torso' of the human figure reminds us of a typical structural pattern from Brittany that combines a hafted axe, a quadrangular motif and an abstract crescent-like motif in a similar arrangement. Some years ago, one of us (SC) offered to interpret the Breton crescent motifs as schematic representations of boats with no crew (Cassen 2007), a hypothesis that seems to be confirmed today by the distant (but nonetheless culturally connected) site of Vallée aux Noirs 6.

The detailed recording of the engravings has enabled us to identify different phases in the execution of the motifs, in particular complex ones such as the axe and the anthropomorphic figure. This 'chronography' is based on the identification of tool marks and patterns in removed rock material, and on relations of anteriority-posteriority that can be detected in overlapping engraved lines.

The axe motif is composed of a 'crook' and an 'axe head' which were executed in this order, as has often been shown in Brittany (Shee-Twohig 1981). The first phase (phase A) focused on the upper curved tip of the crook (Fig. 9) and consisted of a surface preparation in order to remove the superficial 'skin' of the rock that was probably deteriorated here and would have represented a potential risk for the engraving. This part of the crook was then drawn with a thin contour line (phase B), before a first outline of the axe head was made. This outline (and thus the 
type of axe head) was further defined during phase $\mathrm{C}$ together with the rest of the haft. Then, during phase D, the small curvilinear motifs (boar tusks) were added to the lower tip of the haft. Eventually, during the last phase of the sequence (phase E), the ring was engraved over the lower part of the haft in a central position. The engraver, therefore, worked from the top to the bottom.

Such a top-down spatial sequence has not been identified for the anthropomorphic figure, whose more complex arrangement of engraved lines has been ordered differently (Fig. 10). The first phase (A) consisted of the creation of the quadrangular motif divided into two rectangular signs. This initial motif marks the exact geometric centre of the rest of the engravings constituting the character. The head was then partially outlined during phase B, and a face and a kind of hat were integrated. Phase C is marked by the creation of the headdress' 'feathers' or 'flames', with a first group created on the right, then on the left, and in both cases from top to bottom. The outer contour of the figure was made during phase $\mathrm{D}$, including the contour of the nose and eyes. The upper and lower limbs were then 'fixed' to the body (phase E), after which the loincloth was engraved between the legs. Phase F represents an undifferentiated final sequence with the 'beard' below the face on one side, and the small boat on another.

The succession of signs that generates the composite axe motif can hardly be understood as the result of several independent projects: the whole motif is obviously balanced and the combination of an axe, boar tusks and stone ring has been recorded archaeologically for the Neolithic. However, the contemporaneity of all the engraved parts of the anthropomorphic motif is debatable, in particular the anteriority of the two quadrangular signs whose anatomic relevance as a representation of a human body can be questioned. Nevertheless, no significant difference can be seen in execution technique between the geometric figure and the bodily elements of the composition. Overall, the almost perfect symmetrical arrangement of the whole figure suggests that an interpretation can be built on the basis of the entire unified composition.

\section{Acknowledgements}

The 2014 excavation and the OSL dates were funded by the Ministry of Culture (DRAC Ilede-France) and the town council of Buthiers, and the AMS dates supported by the JADE Project (ANRFranche-Comté University), with the help of the University of Nantes, the École Nationale Supérieure d'Architecture of Nantes, E. Vigier (Carnac Museum), D. Simonin (Nemours Museum) and L. Valois (Gersar). We are very grateful to our colleagues C. Chaigneau, D. Caldwell, S. Deschamps, P. François†, E. Gauthier, J. M. Gouedo, Michael Ilett, K. Martin, T. Paulmier, P. Pétrequin, P. Peylet and E. Vartanian for their assistance during and after the fieldwork.

(SC) CNRS, Laboratoire de recherche Archéologie et Architectures (UMR 6566)

Université de Nantes

BP 81227, 44312 Nantes

FRANCE

(Corresponding author) E-mail: serge.cassen@univ-nantes.fr

(VG) Laboratoire de recherche Archéologie et Architectures

Université de Nantes

BP 81227, 44312 Nantes

FRANCE

E-mail:valentin.grimaud@univ-nantes.fr 
(LL) Ecole nationale supérieure d'architecture 6 quai François Mitterrand, 44262 Nantes

FRANCE

E-mail: laurent.lescop@nantes.archi.fr

(CP) Université de Paris 1 Panthéon-Sorbonne (UMR ArScAn 7041, Archéologies environnementales) 3 rue Michelet, 75006 Paris FRANCE E-mail: christophe.petit@univ-paris1.fr

(GR) School of History, Classics and Archaeology, University of Edinburgh William Robertson Wing, Old Medical School, Teviot Place Edinburgh EH8 9AG $U K$ E-mail: guillaume.robin@ed.ac.uk doi: 10.1111/ojoa.12133

\author{
ABBREVIATIONS
}

DOCOB NATURA 2009 Document d'objectifs du site Natura de la Zone Spéciale de Conservation FR 1100799 « Haute vallée de l'Essonne », Tome I: Diagnostic écologique et socio-économique Biotope (Milly-la-Forêt, Parc naturel régional du Gâtinais français).

\title{
REFERENCES
}

BARAY, L. 2016: Les cimetières celtiques du Bassin parisien (VIIe-IIe siècle av. J.-C.): Systèmes typologique et chronologique (Paris).

BAUDET, J.L. 1950: Note préliminaire sur les peintures, gravures et enceintes du Sud de l'Ile-de-France. Bulletin de la Société préhistorique française 47 (6-8), 326-36.

BÉNARD, A. 2011: La Dalle ornée de Rouville, Malsherbes (Loiret). Art Rupestre, bulletin du GERSAR 61, 5-7. BÉNARD A. and GUÉRET C. 2014: Les abris ornés mésolithiques du sud de l'l̂le-de-France: retour critique sur les données archéologiques et perspectives de recherché. In HENRY, A., MARQUEBIELLE, B., CHESNAUX, L. and MICHEL, s. (eds.), Des techniques aux territoires: nouveaux regards sur les cultures mésolithiques, Actes de la table-ronde, 22-23 novembre 2012, Maison de la recherche, Toulouse (France), P@lethnologie $6,138-41$.

CASSEN, S. 2007: Le Mané Lud en images. Interprétation de signes gravés sur les parois d'une tombe à couloir néolithique (Locmariaquer, Morbihan). Gallia-Préhistoire 49,197-258.

CASSEN, S., BOUJOT, C., ERRERA, M.D., MENIER, D., PAILLER Y., PETREQUin, P., MARGUERIE, D., VeYRAT, E., VIGIER, E., POIRIER, S., DAGNEAU, C., DEGEZ, D., LORHO, T., NEVEU-DEROTRIE, H., OBELTZ, C., SCALLIET, F. and SPARFEL, Y. 2010: Un dépôt sous-marin de lames polies néolithiques en jadéitite et sillimanite et un ouvrage de stèles submergé sur la plage dite du Petit Rohu près Saint-Pierre-Quiberon (Morbihan). Bulletin de la Société préhistorique française 107(1), 53-84.

CASSEN, S., LESCOP, L., GRIMAUD, v. and CALDWELL, D. 2014a: Discovery of exceptional Neolithic engravings in Buthiers, Seine-et-Marne, France. Antiquity (Project Gallery) 88(340). http://journal.antiquity.ac.uk/ projgall/cassen 340 . 
CASSEN, S., GRIMAUD, V., LESCOP, L. and CALDWELL, D. 2014b: Le Rocher gravé de la Vallée aux Noirs, Buthiers (Seine-et-Marne). Campagne 2013. Art rupestre, Bulletin du GERSAR 65, 25-37.

CASSEN, S., GRIMAUD, v. and LESCOP, L. 2014c: De l'École à l'Essonne, enregistrements et représentations de gravures néolithiques dans le Gâtinais. In BILlARD, C., BILLARD, C. and DENAIRE, A. (eds.), InterNéo 10, 89-101.

CASSEN, S., GRIMAUD, V., LESCOP, L. and VALOIS, L. 2017: Les compositions gravées en Beauce et Gâtinais. In PÉTREQUIN, P., GAUTHIER, E. and PÉTREQUIN, A.M. (eds.), Objets-signes et interprétations sociales des jades alpins dans l'Europe néolithique (Besançon, Cahiers de la MSHE C.N. Ledoux, Presses Universitaires de Franche-Comté), 761-846.

COURTY, G. 1913: Pétroglyphes figurant des Haches polies. Bulletin de la Société préhistorique française 10(1), $50-4$.

DEVILLIERS, C. 2005: La Dalle gravée de Rouville à Malesherbes (Loiret). Revue archéologique du Loiret hors-série 1, 5-7.

GRIMAUD, v. and CASSEN, s. 2016: De l'usage de la représentation tridimensionnelle pour documenter les architectures funéraires monumentales ornées du Néolithique de l'ouest de la France. Les Nouvelles de l'archéologie 146, 23-7.

HINOUT, J. 1993: La grotte à peinture à Larchant (Seine-et-Marne), lieu-dit Les Dégoûtants à Ratard. Préhistoire et Protohistoire en Champagne-Ardenne 17, 25-91.

LESCOP, L. 2016: Ambiance, Scénologies et patrimoine mégalithique. Livret 2: Ambiance et conception: Cahier méthodologique et technique. Habilitation à diriger des recherches, Université de Nantes, École doctorale: Sciences pour l'Ingénieur, Géosciences et Architecture Discipline: Aménagement de l'espace, Urbanisme Unité de recherche: Centre de Recherche Nantais Architectures Urbanités (Nantes).

PÉTREQUin, P., CASSEN, S., ERRERA, M., KLASSEN, L., SHERIDAN, A. and PÉTREQUIN, A.-M. (eds.) 2012: JADE. Grandes haches alpines du Néolithique européen. $V^{e}$ et $I V^{e}$ millénaires av. J.-C. (Besançon, Les Cahiers de la MSHE Ledoux 17, Série Dynamiques Territoriales 6).

PETREQUin, P., GAUTHIER, E. and PETREQUIN, A.-M. 2017: Jade. Objets-signes et interprétations sociales dans l'Europe néolithique (Besançon, Les Cahiers de la MSHE Ledoux 17; Presses universitaires de Franche-Comté et Centre de recherche archéologique de la vallée de l'Ain 3).

ROUSSOT-LARROQUE, J. 2012: Gigantisme lithique et symboles de pouvoir: les grandes lames en silex de la 'tombe de Chef' de Pauilhac (Gers). In Actes de la table-ronde internationale, L'Europe, déjà, à la fin des temps préhistoriques des grandes lames en silex dans toute l'Europe, Tours (Indre-et-Loire, France), Revue archéologique du centre de la France 38, 191-219.

SHEe-Twohig, E. 1981: The Megalithic Art of Western Europe (Oxford).

TARRETE, J. 1977: Le Montmorencien (Paris, Xe supplément à Gallia-Préhistoire). 